\title{
Chapter 5 \\ Design of a Social Innovation Competence Framework to Educate Entrepreneurs in Developing on the International Stage
}

\author{
Alexandros Yeratziotis, Torgeir Aadland, Sigrid Westad Brandshaug, \\ Christos Mettouris, Evangelia Vanezi, and George Angelos Papadopoulos
}

\begin{abstract}
The European Commission identifies entrepreneurship as one of eight competences necessary for all members of a knowledge-based society. The Entrepreneurship Competence Framework (EntreComp framework) is a tool that European citizens and organisations can utilise to improve entrepreneurial capacity. Social entrepreneurship in particular, has been gaining momentum for numerous reasons. None more so than it being seen as an approach to offer solutions to worldwide social problems. Despite the increasing demand for social entrepreneurship, mainstream internationalization literature for social entrepreneurs remains underdeveloped and little is known about competences social entrepreneurs require to become successful with their internationalization efforts. In this chapter, the social innovation competence framework is presented; empirical work focusing on educating social entrepreneurs to acquire and improve upon competencies needed for going international. The framework, which uses the EntreComp framework as a foundation for its descriptions of the competences, was developed as part of the Erasmus+ project ISSA.
\end{abstract}

Keywords Social innovation competence framework - Social entrepreneur competencies - Internationalization · EntreComp framework

\footnotetext{
A. Yeratziotis $(\triangle) \cdot$ C. Mettouris $\cdot$ E. Vanezi $\cdot$ G. A. Papadopoulos Department of Computer Science, University of Cyprus, Nicosia, Cyprus e-mail: ayerat01@cs.ucy.ac.cy; mettour@cs.ucy.ac.cy; evanez01@cs.ucy.ac.cy; george@cs.ucy.ac.cy

T. Aadland $\cdot$ S. W. Brandshaug

The Norwegian University of Science and Technology, Trondheim, Norway

e-mail: torgeir.aadland@ntnu.no; sigrid.w.brandshaug@ ntnu.no

C. Păunescu et al. (eds.), Social Innovation in Higher Education, Innovation, 


\section{The Key Points of the Chapter Are the Following}

- Review of EntreComp framework.

- Review of social entrepreneurship competences.

- Report on desk research and survey results in the context of ISSA project (Internationalisation for Social and Innovative Start-up's and Entrepreneurs).

- Presentation of the ISSA Competence Framework and its four competencies.

- Contribution of the ISSA Competence Framework towards the internationalization perspectives of European Union's Social Start-Ups.

\section{Introduction}

The project Internationalization for Social and Innovative Start Ups and Entrepreneurs' $\left(\right.$ ISSA $^{1}$ ) main objectives are focused on developing quality and practical lifelong learning support, with a strategic use of information and communication technologies. The project's main target group is existing and potential social entrepreneurs interested in boosting social entrepreneurship and development of social start-ups. The entrepreneurs will be able to move their entrepreneurial efforts internationally, within and beyond the borders of the European Union. More specifically, ISSA is designed to identify core and innovative learning methods that encourage success in international activities for social start-ups and entrepreneurs. The impact of the 2007-2009 Global Financial Crisis has made it necessary to seek for an innovative vision on how to improve economic growth; one of the most attractive options are social entrepreneurs. Although social enterprises are considered as one solution to increase competitiveness and state the importance of crossborder values on European economy, it should be noted by social entrepreneurs that nowadays organisations active on international markets grow faster and are more innovative than those that limit their activities locally. Due to their social activity, it is highly interesting for social enterprises to initiate international relations with similar organisations to promote their objectives at European level (European Commission, 2015).

Participating organisations in the project carry out a project which focuses on improving the internationalization perspectives of the EU's Social Start-Ups. This entails analysing the most frequent problems and barriers for social start-ups within an internationalization process as an endeavour to address these challenges. The project will deliver self-training in practical internationalization and provide entrepreneurship education among social entrepreneurs. This means that the project will aim to reach entrepreneurs beyond the university setting, which has been the main audience in the past, but where calls for change have been made (see e.g., Wiek et al., 2015). The project's innovative self-training course for the internationalization of social start-ups serves as a guide to solve the special needs of social start-ups and

$\overline{{ }^{1} \text { ISSA project website: http://issaproject.eu/ }}$ 
entrepreneurs to receive proper training in essential aspects of the internationalization process. The self-training course will be complemented with an e-learning platform that will work as support for social entrepreneurs. ISSA will also provide and support a proper Virtual Environment to promote social entrepreneurs' attitude about the vital importance of internationalization of the social start-up in early stages. The Virtual Environment will give the entrepreneurs experiences with and training in, for instance, cultural awareness and social opportunities, such that they can obtain insights in important concepts to consider in their internationalisation efforts.

The chapter presents the development of the content for the self-training course. A special focus is on how the competences for the project were selected based on the needs of entrepreneurs in the project partner's countries, in addition to how the development of the definition and content of these competences were prepared. To be able to develop a solid foundation for the project's self-training course, the EntreComp framework (Bacigalupo et al., 2016) serves as a basis for the development of competences adapted for social entrepreneurs. This chapter therefore starts with an introduction to the EntreComp framework. After that, a section on the approach and method employed to select and develop the competences for social and international entrepreneurs follows. The chapter is concluded with main takeaways from the project's approach and results, including a detailed look at the four competences of identifying opportunities, mobilising resources, increasing cultural awareness and an ability to identify social problems all of which are presented.

This chapter's main objectives are to present the development of the social innovation competence framework and to demonstrate an in-depth example of good practice and collaboration within the area of social innovation.

\section{Background and Related Work}

Entrepreneurship is by the European Commission reckoned as one of eight competences necessary for all members of a knowledge-based society. However, being a competence of life-long learning, few consensuses existed in the definition of which competences entrepreneurship constituted of, and thus was the EntreComp framework developed by the Joint Research Centre (JRC) of the European Commission in 2016. The framework consists of three overarching competence areas, building on the definition of entrepreneurship as acting on ideas and opportunities by mobilising resources: 'Ideas and opportunities', 'Resources' and 'Into Action'. These three competence areas constitute 15 competences that together serve as building blocks of entrepreneurship as a competence for all citizens (Bacigalupo et al., 2016).

The 15 different competences are presented along an 8-level progression model, spanning from foundation to expert level, giving learners a way to look at the different learning outcomes presented at each competence. All the 15 competences' learning outcomes sum up to 442 in total, and with an individual descriptor for all competences, the framework gives a detailed description of entrepreneurship and a valuable tool for educational purposes. Moreover, as Bacigalupo et al. (2016) write in the report, the framework should be considered as a starting point and adjusted to 
the individual contexts, and as such, the ISSA project therefore adapts the framework to include its social competences. Thus, the EntreComp framework serves as a foundation for the competences included in the ISSA project, both by using two of its competences and by adapting the framework in the presentation of the social competences applied in the project.

In the past, the framework has been applied and tested in many contexts, for instance in combination with the capability approach in South African primary and secondary schools (Forcher-Mayr \& Mahlknecht, 2020), but also as an assessment tool for entrepreneurship education in Romania (Strauti et al., 2018) and the UK (Dinning, 2019). In the work of Forcher-Mayr and Mahlknecht (2020), the EntreComp framework serves as a framework for inclusion of the capability approach, such that this view is included in a similar structure as the EntreComp's design. In the design of the competences included in the ISSA project, a similar approach was applied, using insights from research on social entrepreneurship as a foundation for the competence descriptions, and utilising the structure from EntreComp in the descriptions of the competences.

\subsection{Social Entrepreneurship-Specific Competence for Internationalization}

The rise of worldwide social problems enables young entrepreneurs to explore social entrepreneurship. Hence, it is this contextual change that has led to social start-ups and businesses being regarded as solutions to global social problems and even considered as part of a global movement (Misbauddin \& Nabi, 2019). Despite this, mainstream internationalization literature for social entrepreneurs remains underdeveloped. There is an increasing demand for social entrepreneurship, but little is known about the competences social entrepreneurs need to possess to become successful (Miller et al., 2012). Social entrepreneurs have most recently increased internationalization efforts, often as a result of an increased globalisation in the world (Zahra et al., 2008). However, this globalisation development also requires additional skills and knowledge with the entrepreneurs, for instance a knowledge perspective of different social problems (Miller et al., 2012) or cultural awareness of the different contexts in which the entrepreneur pursues opportunities (Zahra et al., 2008). In the research on social entrepreneurship, little insights have been obtained regarding the internationalization process, and the competences needed for this process. However, some studies have investigated the competences necessary for social entrepreneurs.

In the work by Miller et al. (2012), the authors identify 35 competences from the literature that social entrepreneurs need in their entrepreneurial efforts, and they further compare these to the educational practices in US higher education. From the study, the authors identify ten competences that are most important for social entrepreneurs such as the ability to solve problems, interpersonal communication 
skills and the ability to develop collaborative relations. The results from this study are further tested by Wronka-Pośpiech (2016) and in her study, she identifies ten competences that she explores in the Polish context. While some of the competences have the same level of importance, the results show that the social entrepreneurs in the two countries differ to some degree in their views regarding the most important competences. Hence, in the development of competences for social entrepreneurs, contextual differences are needed to be considered to ensure that the competences are representative for social entrepreneurs in the project partners' countries. The identified competences are presented in the result section, and the insights in these are partly based on the work by Miller et al. (2012).

Misbauddin and Nabi (2019) present a conceptual framework for the internationalization process of social business (SB) based on an in-depth literature review on social entrepreneurship, SB, and internationalization of small business. Creating a social impact in a foreign location was seen as the main factor behind the internationalization decision. Other factors were entrepreneur-specific, firm-specific, and context-specific ones. The framework highlights opportunity identification and the internationalization implementation phases specifically, while their key contribution resides in the visualisation of an internationalization framework for $\mathrm{SB}$, since it points to gaps and directions within this space. The framework's value towards academia is evident but by including information on the antecedents, opportunity exploitation process, and barriers in the way of SB internationalization, it serves practitioners too, since they can consider it in their expansion efforts and also be made aware of issues required for successful internationalization. The authors point to the lack of empirical research as a limitation in their work and future research opportunities are the identification of weak points of the framework, its validation and refinement through multiple methodologies, e.g. case studies, etc. change and specify (Misbauddin \& Nabi, 2019). The ISSA social innovation competence framework extends work in this area by incorporating empirical work with a focus on educating social entrepreneurs to acquire and improve important competencies towards going international with their social start-ups.

\section{Methodology}

In this section, the ISSA methodology is described. By employing mixed-method modes of enquiry, it will be possible to accomplish the project's objectives. These are: (i) to promote the use of digital self-training for internationalization of European social entrepreneurs and start-ups; (ii) to promote and enhance use of innovative, digital tools and virtual world environments that will motivate social entrepreneurs to use; (iii) to develop a European education and training area via the strategic use of ICTs, which will be available for wide and open use; (iv) to boost internationalization among social entrepreneurships as a measure to increase their benefits; (v) to endorse distance online learning and to create the proper ground for effective 

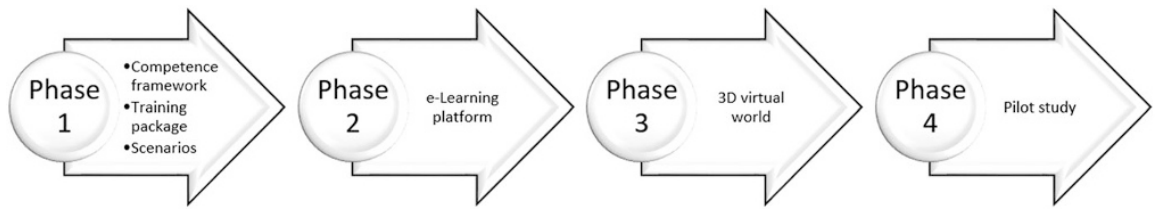

Fig. 5.1 The four-phase methodology of the project

entrepreneurial learning. The four phases of the methodology are presented in Fig. 5.1.

Phase 1 focused on the development of a self-training package that educates social entrepreneurs toward the internationalization of social enterprises. The selftraining package was based on competences selected in relation to ENTRE-COMP and internationalization to ensure its perfect fitting to social enterprises in their road to internationalization. The self-training package also includes self-assessment tests for further encashment of the learning experience. Scenarios were also developed as part of the self-training package.

In Phase 2 the ISSA e-learning platform was designed and developed. Specifically, the Moodle LMS was implemented, hosting all the learning content (. learning material, the related scenarios and the self-assessment tests) Furthermore, the e-learning platform is a space where social start-ups and entrepreneurs can meet, communicate and share experiences and expertise on internationalization issues, expansion plans, sustainable and social entrepreneurship, thus contributing to a sense of a community.

Phase 3 concerns the conceptual design and system architecture of ISSA 3D Virtual World (VW) platform, in which the produced learning content (learning material, the related scenarios and the self-assessment tests) from Phase 2 are "transferred" into the VW. Learners are thus able to test their gained knowledge by implementing the related scenarios of the selected competencies by playing the simulations and/or the experiential learning activities offered in the VW.

Phase 4 is the pilot study. The piloting will aim to ensure that the developed social innovation competence framework, the self-training package, the scenarios, the ISSA e-learning platform and the ISSA 3D VW environment are quality, coherent products which adequately meet their objectives, are relevant to the needs of the social entrepreneurs and have adequate potential for internationalization. The instruments employed will include semi-structured feedback questionnaires with the aim to find out: What are the main advantages and benefits of the developed products? Do they adequately meet the needs of the target audience and the objectives? What are the main learning outcomes? What difficulties the users have met and what improvements need to be made? How to increase the international value of the intellectual products? 


\subsection{Phase 1: ISSA Competence Framework, Training Package and Scenarios: Social Entrepreneurs and Start-Ups Going International}

Each of the four phases, as presented in Sect. 3, consist of several activities. In this chapter, an in-depth discussion on Phase 1 activities 1 and 2 specifically is presented, which lead to the development of a social innovation competence framework to educate social entrepreneurs in going international.

Phase 1 consisted of five activities (see Fig. 5.2). Activity 1 included field research on the ENTRE-COMP competences and determining the skills and competencies for ISSA learners. Activity 2 focused on the adaptation of ENTRE COMP framework and modelling of the ISSA competences description. In Activity 3 , the design and development of the self-training courses was accomplished. Activity 4 focused on the design of the training scenarios and in Activity 5 guidelines for the use of the scenarios and self-training courses were drafted.

In Activity 1, the ENTRE-COMP competences were reviewed, leading to field research on the main target group and in accordance with the country-specific interests of each of the participating countries. A questionnaire was designed and administered which was focused on the competences required to internationalise a social entrepreneurship, which is elaborated further upon next. Considering the

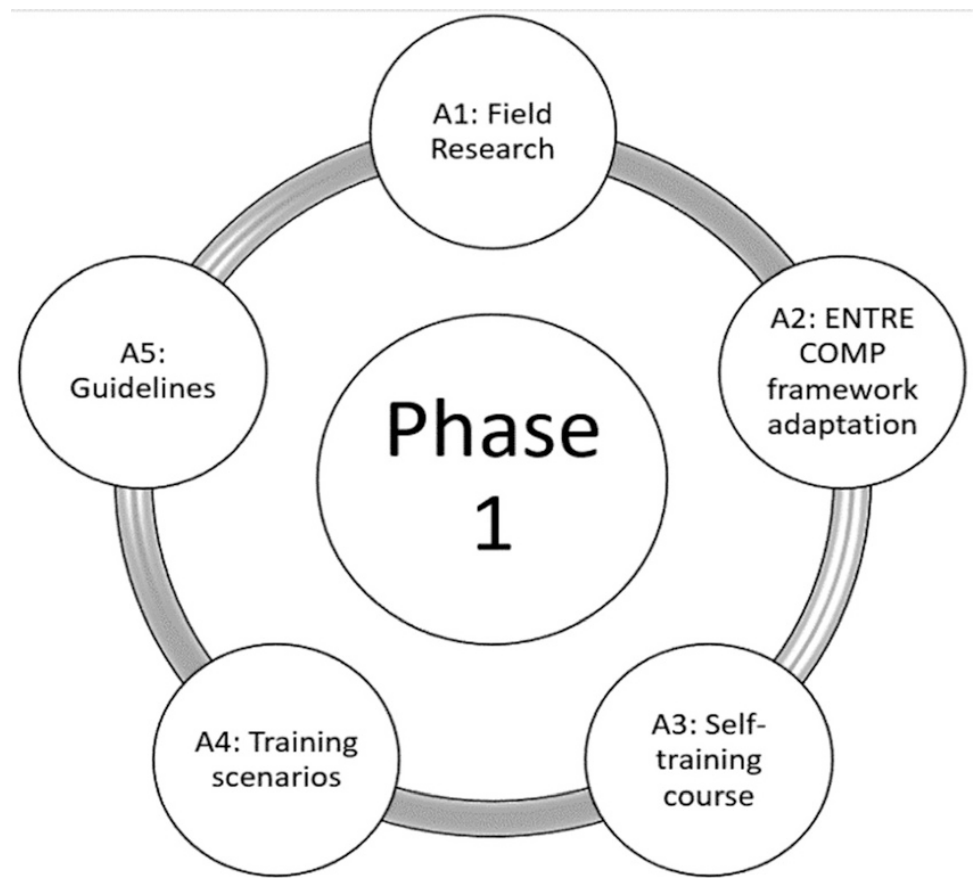

Fig. 5.2 The five activities of Phase 1 
results of Activity 1, it was then possible in Activity 2 to determine the final competences. These competencies were elaborated within the development of the self-training courses (i.e. Activity 3 ) and respective scenarios (i.e. Activity 4). The ISSA competences descriptions were therefore modelled and presented in a report and translated into the languages of the project's partners.

Desk Research To be able to identify the competences that are needed for social entrepreneurs' internationalization efforts, thorough desk and field research investigations were conducted. As mentioned in Sect. 2, previous studies have found differences between countries' needs, hence the desk research attempted to investigate how entrepreneurship and social entrepreneurship is viewed within the different partner countries. Results from the desk research were used to ensure that the survey instrument to be designed would be applicable to investigate important questions and issues identified in the different countries. The desk research revealed several important insights, for instance differences in terms of the general subject of social entrepreneurship and the definition of a social enterprise. Questions regarding topics that could differ between the countries were therefore included in the survey instrument.

Survey Method Based on the desk research, a survey was designed. The main objective of the survey was to identify the different competences to be included in the educational tools developed in the ISSA project. Apart from various control variables (country, organisational type, core team composition), questions regarding social entrepreneurship's level of contribution to the United Nations Sustainable Development Goals, preferred learning approach, difference in competences needed for social entrepreneurship versus traditional entrepreneurship, important competences for social entrepreneurship, and the respondents' organisation's most important entrepreneurial competences were included. The latter two are based on, respectively, Miller et al. (2012) and Wronka-Pośpiech (2016), and on the competences from the European Entrepreneurship Competence Framework. The competences investigated counted 50 in total, and the respondents answered on their level of importance on a scale from a low degree (1) to a very high degree (7).

The survey was distributed digitally through the different partners in the ISSA project to social entrepreneurs in each of the participating countries. Participation was voluntary and 93 full responses were returned. Of the 93 full responses of the survey, 20 respondents came from each of the countries Spain, Greece and Bulgaria (60 in total), nine came from Cyprus, and 24 from Norway. The low number of respondents from Cyprus came from the difficulty in identifying social entrepreneurs in the country. The data was then analysed with SPSS, and the most prominent competencies were identified from the results.

To ensure that all the competencies selected represented the countries' respondents' needs, Chi-Square tests revealed that the countries' respondents differed in terms of the type of organisation they represented, core team composition and their definition of social entrepreneurship. To control for this difference among the respondents, only competences with no significant difference with regards to the 
Table 5.1 Four most important competences for social entrepreneurs in an internationalization process were determined to be Spotting opportunities; Mobilising resources; Ability to identify social problems; and Cultural awareness

\begin{tabular}{l|l}
\hline Focus & Competence \\
\hline \multirow{4}{*}{ Mobilising resources } & Ability to build community support \\
\cline { 2 - 2 } & Develop volunteer \\
\cline { 2 - 2 } & Mobilising resources \\
\cline { 2 - 2 } Social understanding and awareness & Mobilising others \\
\cline { 2 - 2 } & Ability to commit to a collective purpose \\
\cline { 2 - 2 } & Commitment to helping people \\
\cline { 2 - 2 } & Empathy or compassion \\
\cline { 2 - 2 } & Ability to identify social problems \\
\cline { 2 - 2 } & Cultural awareness \\
\cline { 2 - 2 } & Ethical \& sustainable thinking \\
\hline Opportunity development & Creativity \\
\cline { 2 - 2 } & Vision \\
\cline { 2 - 2 } & Valuing ideas \\
\cline { 2 - 2 } & Spotting opportunities \\
\hline Business development & Motivation \& perseverance \\
\cline { 2 - 2 } & Financial \& economic literacy \\
\hline
\end{tabular}

respondents' country of residence, organisation, core team composition and their view of social status were included. Factor and ANOVA analysis was used to identify competences that had a significant difference between the respondents. The competences with the highest level of importance reported by the respondents were included in the course, and in the end four of these were selected by the project participants.

In Table 5.1 below, the list of the competences with the most equal level of importance in all countries is presented. The list consists of competences that do not differ in importance regardless of the respondents' type of organisations, teams and views of social entrepreneurship. The team in the ISSA project then selected the competences spotting opportunities, mobilising resources, cultural awareness and ability to identify social problems. This selection was based on the score of the competence's importance, the desk research, former research, and the insights of the partners in the ISSA project. Two former competences are based on the EntreComp framework, while the latter two are based on the competences found in the literature on social entrepreneurship. The development of the definition of the two new competences then used literature on the subject as a basis for its content, while the structure of the EntreComp framework was used to present the competences. The development of the social entrepreneurship competences are presented in Sect. 4, along with a presentation of the competences mobilising resources and spotting opportunities. 


\section{Results}

In this section the competences of the ISSA social innovation competence framework are presented. First, a summary of EntreComp's descriptions of spotting opportunities and mobilising resources will be presented, before a more thorough explanation of the competences ability to identify social problems and cultural awareness are introduced. Since the ISSA project uses the EntreComp framework as a foundation for its descriptions of the competences, the ISSA competences are therefore presented in a similar manner. The complete ISSA competences table is available online. ${ }^{2}$ The Table shows the levels that social entrepreneurs are able to reach and where they are expected to start. All competences are explained in detail in terms of competence level.

\subsection{Spotting Opportunities}

When moving internationally, social entrepreneurs need to be able to identify opportunities that could contribute to reaching their goals. These opportunities could be sources of funding, new markets, or collaborations. Hence, having the ability to spot opportunities, entrepreneurs could identify opportunities in the international markets that will enable further expansion for their activity, while at the same time maintaining the sustainable focus existing in the business. This competence has the following descriptors (Bacigalupo et al., 2016):

- Identify and seize opportunities to create value by exploring the social, cultural and economic landscape.

- Identify needs and challenges that need to be met.

- Establish new connections and bring together scattered elements of the landscape to create opportunities to create value.

The competence therefore has the following themes in which the learning outcomes are organized: Identify, create and seize opportunities; focus on challenges; uncover needs; analyse the context (Table 5.2).

\subsection{Mobilising Resources}

To be able to act on the opportunities identified, social entrepreneurs need to be able to mobilise resources to reach their goals. This competence therefore revolves around obtaining and marshalling the necessary resources to be able to conduct

\footnotetext{
${ }^{2}$ ISSA competences table: http://www.cs.ucy.ac.cy/seit/wp-content/uploads/2021/02/ISSA_Com petences.pdf
} 


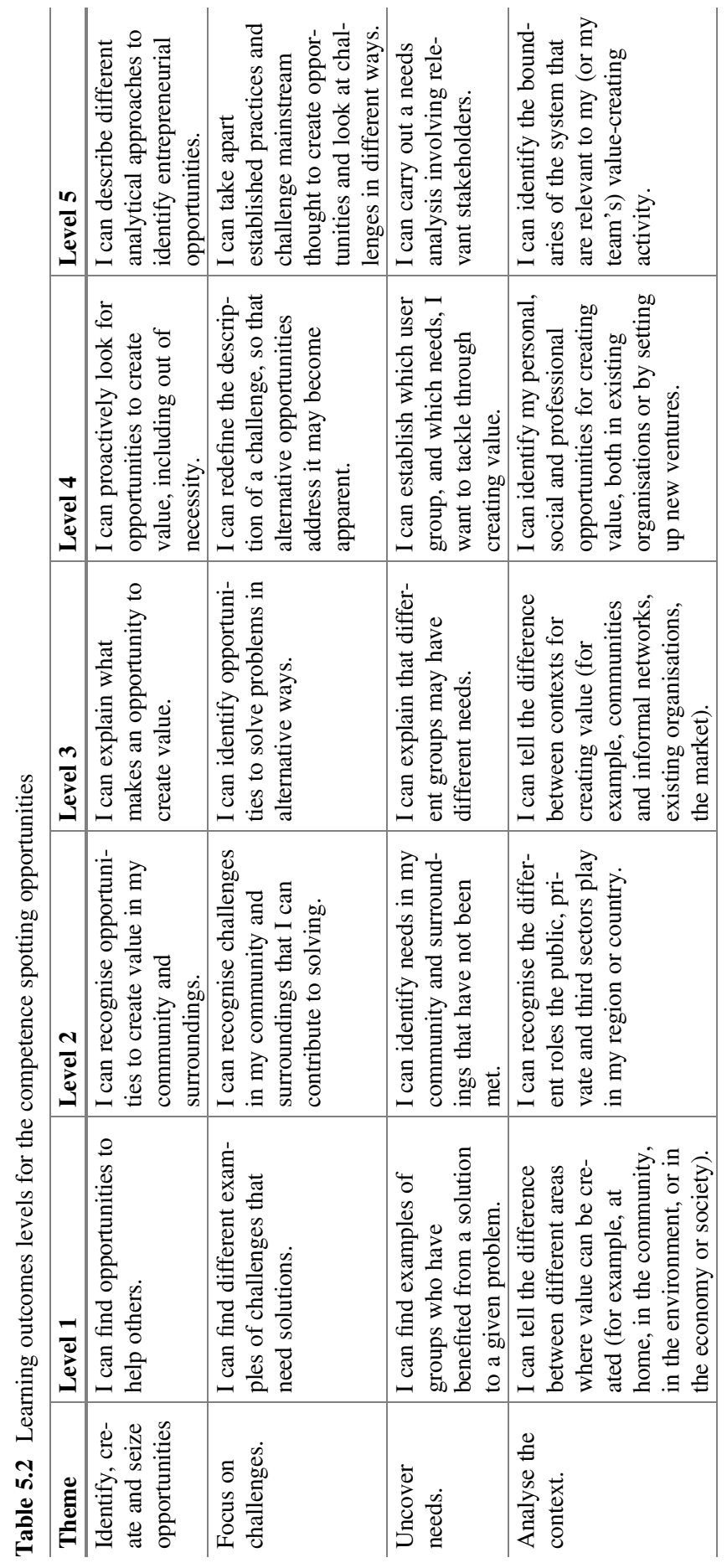


the activities as planned. Thus, by being able to mobilise resources, social entrepreneurs could for instance obtain financing for their efforts, onboard necessary individuals, and ensure the optimal and ethical utilisation of obtained resources. This competence has the following descriptors (Bacigalupo et al., 2016):

- Get and manage the material, non-material and digital resources needed to turn ideas into action.

- Make the most of limited resources.

- Get and manage the competences needed at any stage, including technical, legal, tax and digital competences.

As such, the learning objectives for this competence are organised under the following themes: Manage resources (material and non-material); use resources responsibly; make the most of your time; get support (Table 5.3).

\subsection{Cultural Awareness}

Helping entrepreneurs in understanding the cultural differences that might emerge when moving into different international markets and regions, reducing problems connected to cultural differences. Knowing what is and is not permitted or expected or considered legitimate by social and cultural standards is key to developing successful social entrepreneurial strategies and operational plans (Dacin et al., 2010).

The predominant approach to explore cultural differences is the six cultural dimensions from Hofstede $(1980,2001)$, which has been extended to nine dimensions in the GLOBE study (House et al., 2004), and further applied in the context of social entrepreneurship (Canestrino et al., 2020). These nine dimensions are Power Distance, Uncertainty Avoidance, In-group Collectivism, Institutional Collectivism, Gender Egalitarianism, Performance Orientation, Future Orientation, Human Orientation and Assertiveness. Based on the above, this competence has the following descriptors (Table 5.4):

- Identify and analyse dimensions in another culture.

- See positive and negative aspects of cultures and tolerate differences.

- Manage differences by communicating effectively and see opportunities from having an "outsider perspective".

- The learning objectives for cultural awareness are therefore organised under the following themes: Cultural dimensions, tolerance and cultural differences.

\subsection{Ability to Identify Social Problems}

Social problems exist in many countries, regions and contexts, and as a social entrepreneur, it is necessary to be able to identify social problems in varying 


\begin{tabular}{|c|c|c|c|c|}
\hline 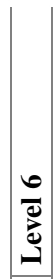 & 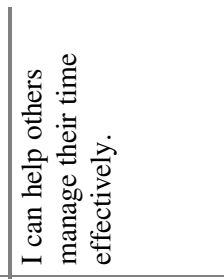 & 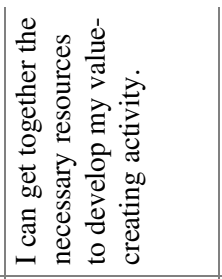 & 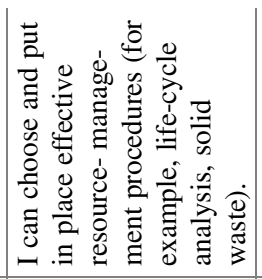 & \\
\hline n & 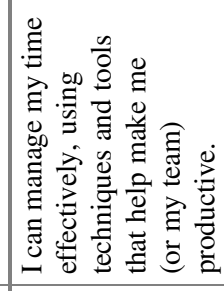 & 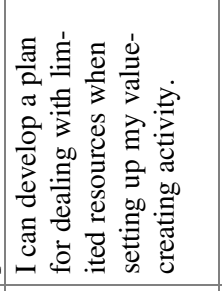 & 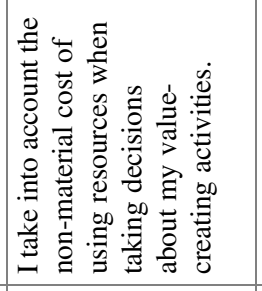 & 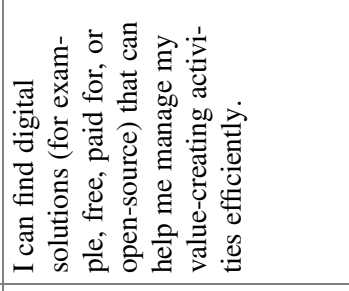 \\
\hline 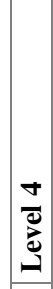 & 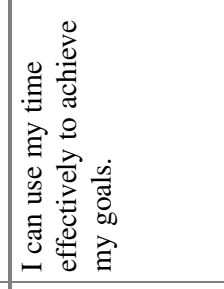 & 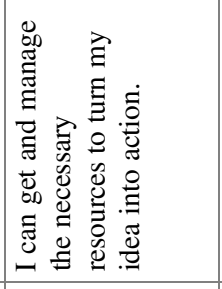 & 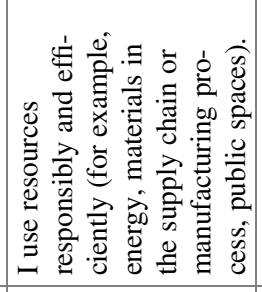 & 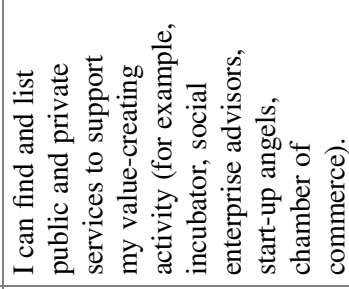 \\
\hline m & 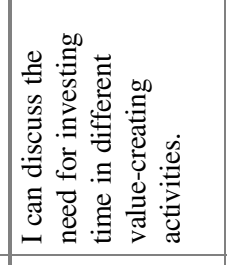 & 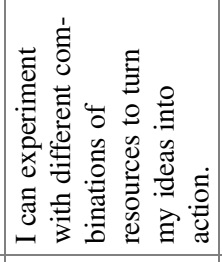 & 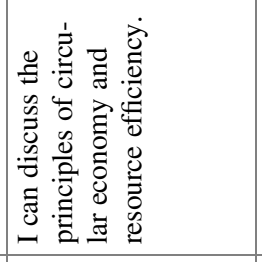 & 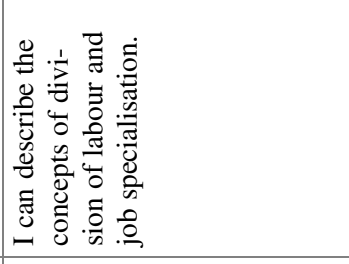 \\
\hline لَ & & & & 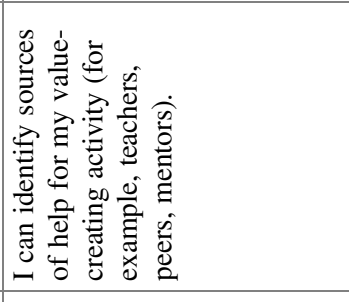 \\
\hline כ) & & & & 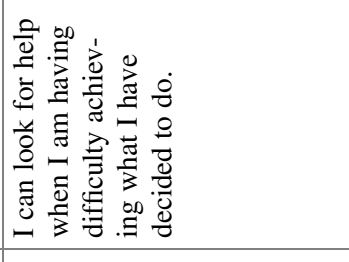 \\
\hline$\underset{E}{\stackrel{\Xi}{E}}$ & 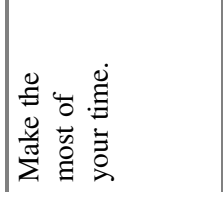 & 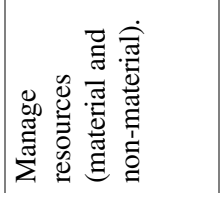 & 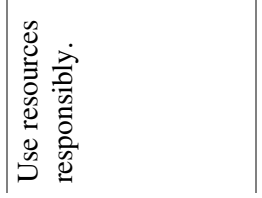 & 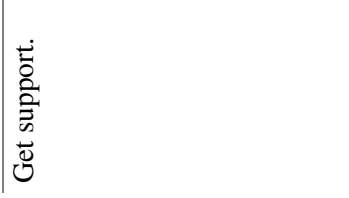 \\
\hline
\end{tabular}




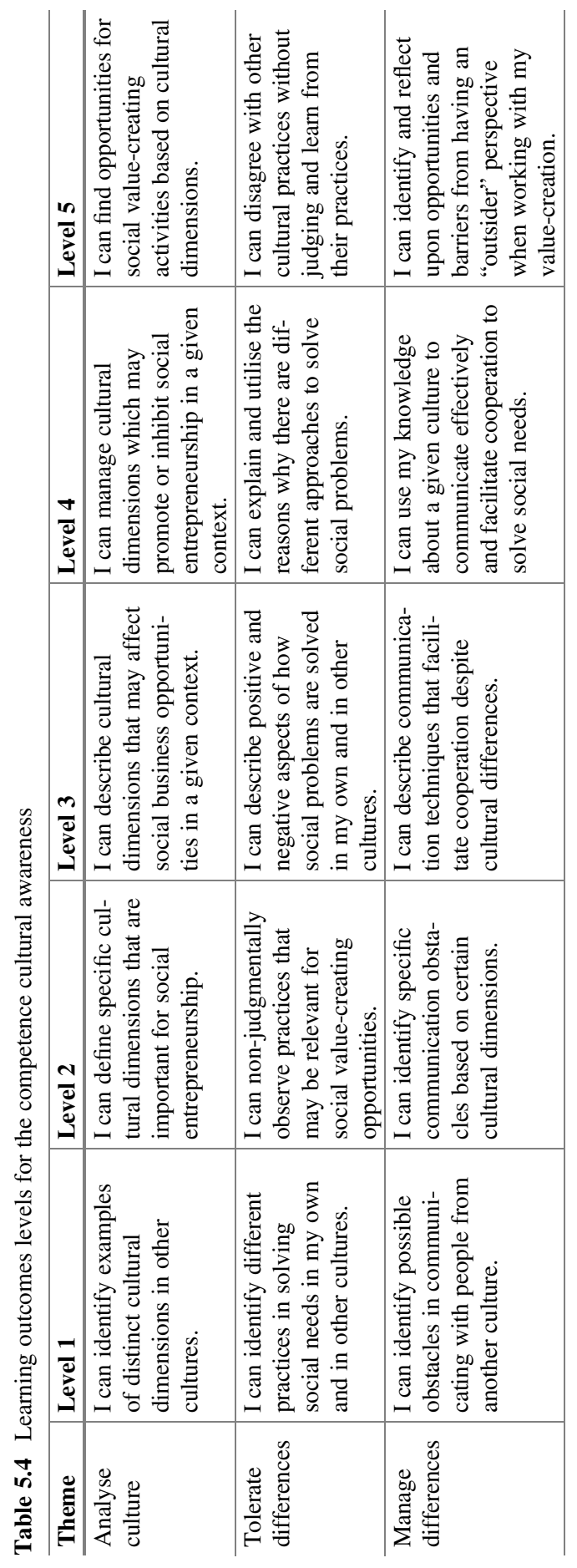


situations (Miller et al., 2012). Different problems require different approaches and solutions, and often the entrepreneur need to implement innovative solutions, both at the managerial level and in the organisation's solutions (Shaw \& Carter, 2007; Zahra et al., 2008). To do this, the entrepreneur need to have insights in the problems, the system the problems are embedded in, and the contextual uniqueness and similarity to other contexts. The entrepreneur needs to utilise prior knowledge about the context and be innovative in the understanding of the system to be able to develop sufficient solutions (Zahra et al., 2008).

Moreover, as value creation is central in entrepreneurship, and especially the creation of social value for social entrepreneurs, an understanding of total wealth is needed in the task of identifying social problems (Sullivan Mort et al., 2003; Zahra et al., 2008). Having the necessary insights in the potential of total wealth in a system, that is, the sum of social and economic wealth, will help the entrepreneur understand the problems' complexity in the system in which they exist (Zahra et al., 2008). Thus, the competence ability to identify social problems has the following descriptors:

- Identify and analyse social problems in various contexts.

- Use social wealth as a measure to analyse and discuss social problems.

- Understand the system in which social problems exist, including the efforts needed to initiate processes intended to reduce the social problems.

Furthermore, the learning objectives for the competence are organised under the following themes (Table 5.5): Systems of social problems; contextual knowledge; social wealth.

In Table 5.6 below, the different competences in the ISSA project are summarised. The different competences, descriptors along with the competences' learning outcomes are also presented in ISSA competences table online ${ }^{2}$.

\section{Conclusions}

This chapter illustrates the development of new competencies to be used in an online self-training course for social entrepreneurs going internationally. The competences developed utilises the EntreComp framework as a structural basis while its content is developed from subject specific literature. The chapter therefore presents practice for further inspiration and development in the creation of competencies for different contexts and subjects, especially with an international audience in focus.

The chapter contributes in several ways. First, it presents a method for the development of competencies, where cultural and contextual differences are identified in a stepwise manner and controlled for in the development. The difference between countries in terms of the importance of social entrepreneurship competences was already identified in the literature prior to the project, and the project's research confirmed and controlled for this. While the research approach took methodological considerations to ensure its results, the study was, however, conducted in 
Table 5.5 Learning outcomes levels for the competence ability to identify social problems

\begin{tabular}{|c|c|c|c|c|c|}
\hline Theme & Level 1 & Level 2 & Level 3 & Level 4 & Level 5 \\
\hline $\begin{array}{l}\text { Understand } \\
\text { social } \\
\text { wealth. }\end{array}$ & $\begin{array}{l}\text { I can iden- } \\
\text { tify different } \\
\text { constituents } \\
\text { of social } \\
\text { wealth: } \\
\text { Social value } \\
\text { and social } \\
\text { costs. }\end{array}$ & $\begin{array}{l}\text { I can iden- } \\
\text { tify differ- } \\
\text { ent levels } \\
\text { of social } \\
\text { value and } \\
\text { social } \\
\text { costs. }\end{array}$ & $\begin{array}{l}\text { I can describe the } \\
\text { relations and } \\
\text { interconnections } \\
\text { between social } \\
\text { value and costs. }\end{array}$ & $\begin{array}{l}\text { I can evaluate } \\
\text { different con- } \\
\text { stituents and } \\
\text { combinations } \\
\text { of social value } \\
\text { and costs in my } \\
\text { work to iden- } \\
\text { tify those that } \\
\text { optimise a } \\
\text { solution. }\end{array}$ & $\begin{array}{l}\text { I can evaluate } \\
\text { the social } \\
\text { values and } \\
\text { costs in a sys- } \\
\text { tem including } \\
\text { economic } \\
\text { wealth to } \\
\text { identify the } \\
\text { best solutions. }\end{array}$ \\
\hline $\begin{array}{l}\text { Utilise con- } \\
\text { textual } \\
\text { knowledge. }\end{array}$ & $\begin{array}{l}\text { I can iden- } \\
\text { tify social } \\
\text { problems in } \\
\text { my context. }\end{array}$ & $\begin{array}{l}\text { I can iden- } \\
\text { tify the } \\
\text { main driv- } \\
\text { ing forces } \\
\text { of my } \\
\text { context's } \\
\text { social } \\
\text { problems. }\end{array}$ & $\begin{array}{l}\text { I can identify the } \\
\text { characteristics of } \\
\text { my context and } \\
\text { identify similar } \\
\text { contexts with } \\
\text { similar social } \\
\text { problems. }\end{array}$ & $\begin{array}{l}\text { I can identify } \\
\text { measures to } \\
\text { create value } \\
\text { that could } \\
\text { decrease my } \\
\text { context's } \\
\text { social prob- } \\
\text { lems, based on } \\
\text { other contexts' } \\
\text { measures. }\end{array}$ & $\begin{array}{l}\text { I can develop } \\
\text { measures to } \\
\text { reduce social } \\
\text { problems used } \\
\text { in other con- } \\
\text { texts to fit in } \\
\text { my own } \\
\text { context. }\end{array}$ \\
\hline $\begin{array}{l}\text { Analyse the } \\
\text { system. }\end{array}$ & $\begin{array}{l}\text { I can iden- } \\
\text { tify social } \\
\text { problems } \\
\text { that exist in } \\
\text { a system. }\end{array}$ & $\begin{array}{l}\text { I can iden- } \\
\text { tify } \\
\text { changes } \\
\text { that would } \\
\text { reduce the } \\
\text { system's } \\
\text { social } \\
\text { problems. }\end{array}$ & $\begin{array}{l}\text { I can think of } \\
\text { well-known } \\
\text { approaches that } \\
\text { could reduce the } \\
\text { system's social } \\
\text { problems. }\end{array}$ & $\begin{array}{l}\text { I can imagine } \\
\text { new and novel } \\
\text { ways of reduc- } \\
\text { ing a system's } \\
\text { social } \\
\text { problems. }\end{array}$ & $\begin{array}{l}\text { I can assess } \\
\text { the plausibil- } \\
\text { ity whether } \\
\text { different solu- } \\
\text { tions fit in the } \\
\text { system. }\end{array}$ \\
\hline
\end{tabular}

five European countries and with a limited number of respondents. Other countries and context might identify other competences that are of higher importance for their entrepreneur. Furthermore, the method also utilises the EntreComp framework and illustrates how this framework could serve as a structural guideline in the development of descriptions of new entrepreneurship competences.

Second, the chapter also contributes to social entrepreneurship literature through the development of the descriptions of the competences ability to identify social problems and cultural awareness. These competences' content are based on central and important literature on the topic, but should in the future be tested and verified by active social entrepreneurs with experience in internationalization of their entrepreneurial efforts. Future work is targeted towards more empirical work on the Social Innovation Competence Framework. More specifically, this includes the evaluation of the self-training packages, e-learning platform, 3D VW and scenarios with social entrepreneurs to measure whether they improve upon the competences that will support them in the internationalization process of their social enterprises. 
Table 5.6 ISSA competences' hints and descriptors

\begin{tabular}{|c|c|c|}
\hline Competences & Hints & Descriptors \\
\hline $\begin{array}{l}\text { Spotting } \\
\text { opportunities }\end{array}$ & $\begin{array}{l}\text { Use your imagination and abilities to } \\
\text { identify opportunities for creating } \\
\text { value }\end{array}$ & $\begin{array}{l}\text { - Identify and seize opportunities to } \\
\text { create value by exploring the social, } \\
\text { cultural and economic landscape } \\
\text { - Identify needs and challenges that } \\
\text { need to be met } \\
\text { - Establish new connections and bring } \\
\text { together scattered elements of the } \\
\text { landscape to create opportunities to } \\
\text { create value }\end{array}$ \\
\hline $\begin{array}{l}\text { Mobilizing } \\
\text { resources }\end{array}$ & $\begin{array}{l}\text { Gather and manage the resources } \\
\text { you need }\end{array}$ & $\begin{array}{l}\text { - Get and manage the material, } \\
\text { non-material and digital resources } \\
\text { needed to turn ideas into action } \\
\text { - Make the most of limited resources } \\
\text { - Get and manage the competences } \\
\text { needed at any stage, including techni- } \\
\text { cal, legal, tax and digital competences }\end{array}$ \\
\hline $\begin{array}{l}\text { Ability to iden- } \\
\text { tify social } \\
\text { problems }\end{array}$ & $\begin{array}{l}\text { Using imagination, knowledge and } \\
\text { experience to identify social } \\
\text { problems. }\end{array}$ & $\begin{array}{l}\text { - Identify and analyse social problems } \\
\text { in various contexts } \\
\text { - Use social wealth as a measure to } \\
\text { analyse and discuss social problems } \\
\text { - Understand the system in which } \\
\text { social problems exist, including the } \\
\text { efforts needed to initiate processes } \\
\text { intended to reduce the social problems }\end{array}$ \\
\hline $\begin{array}{l}\text { Cultural } \\
\text { awareness }\end{array}$ & $\begin{array}{l}\text { Identify and manage cultural } \\
\text { differences. }\end{array}$ & $\begin{array}{l}\text { - Identify and analyse dimensions in } \\
\text { another culture. } \\
\text { - See positive and negative aspects of } \\
\text { cultures and tolerate differences. } \\
\text { - Manage differences by communicat- } \\
\text { ing effectively and see opportunities } \\
\text { from having an 'outsider perspective'. }\end{array}$ \\
\hline
\end{tabular}

Acknowledgments This work is supported by the European Commission as part of the ISSA Erasmus+ project funded by the 2019 Programme Call-KA2 - Cooperation for innovation and the exchange of good practices: KA204-Strategic Partnerships for adult education-under grant agreement no 2019-1-NO01-KA204-060263.

\section{References}

Bacigalupo, M., Kampylis, P., Punie, Y., \& Van den Brande, G. (2016). EntreComp: The entrepreneurship competence framework. Publication Office of the European Union. https://doi.org/ $10.2791 / 593884$

Canestrino, R., Ćwiklicki, M., Magliocca, P., \& Pawełek, B. (2020). Understanding social entrepreneurship: A cultural perspective in business research. Journal of Business Research, 110, 132-143. https://doi.org/10.1016/j.jbusres.2020.01.006 
Dacin, P., Dacin, M., \& Matear, M. (2010). Social entrepreneurship: Why we don't need a new theory and how we move forward from here. Academy of Management Perspectives, 24(3), 37-57. https://doi.org/10.5465/AMP.2010.52842950

Dinning, T. (2019). Articulating entrepreneurial competencies in the undergraduate curricular. Education and Training, 61(4), 432-444. https://doi.org/10.1108/ET-09-2018-0197

European Commission. (2015). A map of social enterprises and their eco-systems in Europe. https://doi.org/10.2767/458972

Forcher-Mayr, M., \& Mahlknecht, S. (2020). A capability approach to entrepreneurship education: The sprouting entrepreneurs Programme in rural south African schools. Discourse and Communication for Sustainable Education, 11(1), 119-133. https://doi.org/10.2478/dcse-2020-0011

Hofstede, G. (1980). Culture and organizations. International Studies of Management \& Organization, 10(4), 15-41. https://doi.org/10.1080/00208825.1980.11656300

Hofstede, G. (2001). Culture's consequences: Comparing values, behaviors, institutions and organizations across nations. SAGE Publications.

House, R. J., Hanges, P. J., Javidan, M., Dorfman, P. W., \& Gupta, V. (2004). Culture, leadership, and organizations: The GLOBE study of 62 societies. SAGE Publications.

Miller, T. L., Wesley, C. L., \& Williams, D. E. (2012). Educating the minds of caring hearts: Comparing the views of practitioners and educators on the importance of social entrepreneurship competencies. Academy of Management Learning and Education, 11(3), 349-370. https:// doi.org/10.5465/amle.2011.0017

Misbauddin, S. M., \& Nabi, M. N. U. (2019). Internationalization of social business: Toward a comprehensive conceptual understanding. In societal entrepreneurship and competitiveness (pp. 117-136). Emerald Publishing Limited. https://doi.org/10.1108/978-1-83867471-720191009

Shaw, E., \& Carter, S. (2007). Social entrepreneurship: Theoretical antecedents and empirical analysis of entrepreneurial processes and outcomes. Journal of Small Business and Enterprise Development, 14(3), 418-434. https://doi.org/10.1108/14626000710773529

Strauti, G., Dumitrache, V.-M., \& Taucean, I. M. (2018). Entrepreneurial competences in economical engineering curriculum in Romania. Procedia-Social and Behavioral Sciences, 238, 737-742. https://doi.org/10.1016/j.sbspro.2018.04.057

Sullivan Mort, G., Weerawardena, J., \& Carnegie, K. (2003). Social entrepreneurship: Towards conceptualisation. International Journal of Nonprofit and Voluntary Sector Marketing, 8(1), 76-88. https://doi.org/10.1002/nvsm.202

Wiek, A., Bernstein, M. J., Foley, R. W., Cohen, M., Forrest, N., Kuzdas, C., Kay, B., \& Keeler, L. W. (2015). Operationalising competencies in higher education for sustainable development. In M. Barth, G. Michelsen, M. Rieckmann, \& I. Thomas (Eds.), Routledge handbook of higher education for sustainable development (pp. 241-260). Routledge. https://doi.org/10.4324/ 9781315852249

Wronka-Pośpiech, M. (2016). The identification of skills and competencies for effective management in social enterprises. A managerial perspective. Management, 20(1), 40-57. https://doi. org/10.1515/manment-2015-0023

Zahra, S. A., Rawhouser, H. N., Bhawe, N., Neubaum, D. O., \& Hayton, J. C. (2008). Globalization of social entrepreneurship opportunities. Strategic Entrepreneurship Journal, 2(2), 117-131. https://doi.org/10.1002/sej.43 


\begin{abstract}
Alexandros Yeratziotis, is a Post-Doctoral Researcher at the SEIT laboratory, Dept. of Computer Science, University of Cyprus and Visiting Lecturer at the Multimedia and Graphic Arts Department at the Cyprus University of Technology. He is co-founder of Connect Deaf, a startup offering accessible communication and educational mobile apps for users who are deaf. Topic of his previous post-doctoral research position was Usability and User Experience User Interface Design Heuristics for Deaf Users, funded by the National Research Foundation of South Africa (NRF). He received his doctorate from the School of Information and Communication Technology at the Nelson Mandela Metropolitan University (NMMU), which was co-funded by the NMMU, South Africa-Finland Knowledge Partnership on ICT (SAFIPA) and the German Academic Exchange Service/Deutscher Akademischer Austauschdienst Dienst (DAAD/NRF). He has published in the field of Human-Computer Interaction and has served as a reviewer in wellknown journals. Research interests: HCI, user experience (UX), accessible computing, usercentered design and usability inspection methods.
\end{abstract}

Torgeir Aadland is Associate Professor in Entrepreneurship at the Norwegian University of Science and Technology (NTNU). His research interest is in entrepreneurship education and early venture performance and strategy. He has published several articles, book chapters and reports on entrepreneurship education, focusing especially on its design, learning approaches and outcomes. He has experience as an entrepreneur and is educated at the NTNU School of Entrepreneurship, where he over the latter years has been part of its faculty. Aadland is also co-director of Engage-Centre for Engaged Education through Entrepreneurship, a centre for excellence in entrepreneurship education. He is participating in several international projects focusing on developing new learning initiatives in entrepreneurship education, and in various research projects on entrepreneurship and entrepreneurship education.

Sigrid Westad Brandshaug is a PhD candidate in Engage, Centre for Engaged Education through Entrepreneurship at NTNU. Sigrid has been working as a university teacher and facilitator at the section for Experts in Teamwork at NTNU. Her research interest is on team processes and student learning in Entrepreneurship Education.

Christos Mettouris, is a graduate of the polytechnic school of Computer Engineering \& Informatics Department at the University of Patras, Greece. He holds a Masters' degree of the same department and a PhD degree from the University of Cyprus. He has been a member of the e-Learning sector of the Research Academic Computer Technology Institute (RACTI) in Greece. $\mathrm{He}$ is currently a Post-Doctoral Researcher at the University of Cyprus and a member of the Software Engineering and Internet Technologies (SEIT) Lab of the Computer Science Department. $\mathrm{He}$ is involved in a number of EU and local funded projects (SCIChallenge-H2020, Prosperity4AllFP7, Asterics-FP7, idSpace-FP7, CVN-AAL, B3Regions, InnoFun and more) and was also involved in the organization of a number of conferences in Cyprus (DSD-SEAA 2016, ICEIRD 2014, ICSOB 2014, BIS 2014, WiMob 2014, to name a few of them). His research interests include Recommender Systems, Ubiquitous Computing, Model-Driven Development and Context-Aware Computing.

Evangelia Vanezi, is currently Researcher at the Software Engineering and Internet Technologies (SEIT) Laboratory at the Computer Science department of the University of Cyprus. As a member of the laboratory she is involved in numerous EU funded projects. She holds a graduate (B.Sc.) degree in Computer Science and a post-graduate (M.Sc.) degree in Internet Computing, from the same department. She is currently pursuing a $\mathrm{PhD}$ degree. Her research interests and expertise include Web-based Software Engineering, User Management Systems Development, Privacy in Software Systems, Data Protection in Software Systems, Privacy verification in Software Systems, Formal Methods in Software Engineering Methodologies and Privacy by Design in Software Development. Her skills include programming in several languages and developing of web and mobile applications. 
George Angelos Papadopoulos, holds the (tenured) rank of Professor in the Department of Computer Science of the University of Cyprus. He has participated in a number of international and national projects both as a researcher or partner, and as a co-coordinator. He has been involved in the organisation and Program Committees of more than 100 international conferences and workshops. Professor Papadopoulos' research interests include component-based systems, mobile computing, multimedia systems, e-learning, open and distance learning, parallel programming and high-performance computing, GRID technologies, electronic commerce, workflow management and CSCW. He has published over 100 papers as book chapters or in internationally refereed journals and conferences and he serves in the Editorial Board of 5 international journals. He has been involved or is currently participating, as coordinator or partner, in over 30 internationally and nationally funded projects (total budget for his participation about 6 MEURO). He is the Director of the SEIT Lab.

Open Access This chapter is licensed under the terms of the Creative Commons Attribution 4.0 International License (http://creativecommons.org/licenses/by/4.0/), which permits use, sharing, adaptation, distribution and reproduction in any medium or format, as long as you give appropriate credit to the original author(s) and the source, provide a link to the Creative Commons license and indicate if changes were made.

The images or other third party material in this chapter are included in the chapter's Creative Commons license, unless indicated otherwise in a credit line to the material. If material is not included in the chapter's Creative Commons license and your intended use is not permitted by statutory regulation or exceeds the permitted use, you will need to obtain permission directly from the copyright holder. 